\title{
Physical and optical properties of aerosols over an urban location in Spain: seasonal and diurnal variability
}

\author{
H. Lyamani, F. J. Olmo, and L. Alados-Arboledas \\ Departamento de Física Aplicada, Universidad de Granada, 18071 Granada, Spain \\ Centro Andaluz de Medio Ambiente, Junta de Andalucía, Universidad de Granada, 18006 Granada, Spain \\ Received: 6 March 2009 - Published in Atmos. Chem. Phys. Discuss.: 2 September 2009 \\ Revised: 24 November 2009 - Accepted: 19 December 2009 - Published: 13 January 2010
}

\begin{abstract}
Measurements of aerosol optical properties and aerosol number size distribution obtained during the period from December 2005 to November 2007 at Granada, an urban site in south-eastern Spain, are analyzed. Large variations of the measured variables have been found, and related to variations in emissions sources and meteorological conditions. High values of aerosol absorption and scattering coefficients are obtained during winter and low values are measured during summer. This seasonal pattern in the surface aerosol optical properties is opposite to the seasonal cycle showed by columnar aerosol optical depth. The differences in the seasonal features of the surface and column-integrated data are related to seasonal variations in the aerosol vertical distribution, aerosol sources and boundary layer height. In winter the number density of "fine" particles $(0.5<$ particle diameter $<1 \mu \mathrm{m})$ is significantly larger than in summer while the number density of "coarse" particles $(1<$ particle diameter $<20 \mu \mathrm{m})$ is slightly larger during summer and spring than during winter and autumn. The scattering Angström exponent, $\alpha_{\mathrm{s}}$, presents an evident seasonal cycle with values of $1.8 \pm 0.2,1.6 \pm 0.3,1.3 \pm 0.3$ and $1.4 \pm 0.3$ in winter, spring, summer and autumn, respectively. This suggests the presence of a large fraction of submicron particles at the site, especially during winter. The aerosols measured in this study contain a large fraction of absorbing material as indicated by the average single-scattering albedo that has values of $0.65 \pm 0.07,0.66 \pm 0.06,0.70 \pm 0.06$ and $0.73 \pm 0.06$ in autumn, winter, spring and summer, respectively. The aerosol scattering albedo obtained in the surface boundary layer of Granada is below the critical value of 0.86 that determines the shift from cooling to warming. These
\end{abstract}

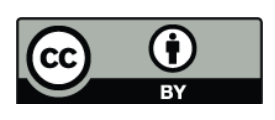

Correspondence to:

L. Alados-Arboledas

(alados@ugr.es) results put in evidence the need of efforts to reduce absorbing particles (black carbon) emissions to avoid the possible warming that would result from the reductions of the cooling aerosols only. The aerosol absorption and scattering coefficients present a clear diurnal pattern, in all seasons, with two local maxima, one early in the morning and the second one in the evening. This diurnal cycle is mainly attributed to the diurnal evolution of atmospheric boundary layer and local anthropogenic activities.

\section{Introduction}

Atmospheric aerosol particles are one of the most variable components of the Earth's atmosphere, and are known to influence the energy budget and climate. Aerosol particles affect the Earth's radiative balance and climate directly by absorbing and scattering solar radiation (Haywood and Shine, 1997; Forster et al., 2007), and indirectly by acting as cloud condensation nuclei, changing thus the microphysical properties of clouds (Kaufman et al., 2005; Forster et al., 2007). Also, aerosol particles play a major role in atmospheric chemistry and so affect the densities of other minor atmospheric constituents like ozone (Schwartz et al., 1995). Furthermore, aerosol particles have been implicated in human health effects (Dockery and Pope, 1996) and visibility reduction in urban and regional areas (Horvath, 1995).

Aerosol particle types which contribute to the scattering coefficient include organic particles, water-soluble inorganic species such as sulphates, nitrates etc. that are produced by conversion from $\mathrm{SO}_{2}$ and $\mathrm{NO}_{\mathrm{x}}$ associated mainly with fossil fuel/biomass combustion, and ammonium from fertilizers and biological sources. In addition, dust and sea salt may also contribute significantly to the aerosol scattering

Published by Copernicus Publications on behalf of the European Geosciences Union. 
characteristics in certain conditions. In an urban site, black carbon is the principle particle species that absorbs radiation in the visible spectrum. Black carbon is produced as primary particles from incomplete combustion processes, in particular from diesel engines, which are the major source of black carbon in urban areas (Jacobson, 2001). In addition, the hematite found in mineral dust is one of the particulate substances that appreciably contribute to absorption at wavelength less than $500 \mathrm{~nm}$, but its absorption of visible light is negligible compared to that of black carbon (Heintzenberg, 1982; Dubovik et al., 2002).

In contrast to the greenhouse gases which only cause warming, atmospheric aerosol particles, depending on their composition, can cause either cooling or warming of the atmosphere (Hansen et al., 1997). However, despite significant progress in understanding aerosol effects on climate there are still significant uncertainties due to the lack of adequate information on the temporal and spatial variability of aerosol particles and their associated properties across the globe (Forster et al., 2007). In this sense long range transport events like Saharan dust outbreaks (Lyamani et al., 2005; Lyamani et al., 2006a; Lyamani et al., 2006b; GuerreroRascado et al., 2009) or global scale events like stratospheric aerosols following major volcanic eruptions like El Chichón and Mount Pinatubo (Olmo and Alados-Arboledas, 1995) represent extreme cases of this variability. Hence, it is important to monitor aerosol properties across various places on the Earth, in order to establish a comprehensive picture of aerosols and their climatic and environmental impacts. Understanding the influence of atmospheric aerosol on climate, visibility and photochemistry requires knowledge of their optical and physical properties, such as the light extinction coefficient (the sum of the aerosol light scattering and absorption coefficients), single scattering albedo (ratio of scattering to extinction coefficients), upscatter fraction (fraction of incident solar radiation that is scattered upward to space), and size distribution (e.g. Waggoner et al., 1981; Haywood and Boucher, 2000; Alados-Arboledas et al., 2003; AladosArboledas et al., 2008).

Measurements of the aerosol absorption coefficient in Europe are relatively scarce, at least when compared with the abundance of scattering measurements. Currently, aerosol light absorption measurements typically show larger uncertainties than do scattering measurements (Bond et al., 2006). Thus, it is essential to use a technique that determines the aerosol absorption coefficient with relatively high accuracy. At this time, the Multi-Angle Absorption Photometer (MAAP) is the most reliable filter-based instrument for continuous atmospheric aerosol absorption measurements (Petzold and Schönlinner 2004; Petzold et al., 2005). The MAAP simultaneously measures radiation transmitted through and scattered back from particles deposited on the filter and uses radiative transfer calculations to determine the aerosol absorption coefficient to correct for errors that occur in other conventional instruments (Petzold and Schönlinner 2004).
This explicit treatment of light scattering effects caused by aerosol and filters matrix improve considerably the determination of aerosol absorption over other filter based methods, as demonstrated by comparison with reference method (Petzold et al., 2005; Sheridan et al., 2005). Thus, this instrument provides aerosol absorption coefficient without further need for data correction (Petzold and Schönlinner 2004; Petzold et al., 2005). In this study, we used a MAAP for a better determination of aerosol absorption coefficient.

In this work we present results on various aerosol optical and physical variables that were measured at Granada, Spain, during the period from December 2005 to November 2007. Important aerosol parameters studied at this urban location include scattering and absorption coefficients, scattering coefficient spectral dependence, single scattering albedo, backscattering ratio, aerosol size distributions as well as columnar aerosol optical depth. Meteorological parameters that influence these aerosol properties, like wind speed and ambient temperature, are also analyzed. Seasonal and diurnal variations of these parameters and the influence of meteorological conditions are also analyzed and explained.

The experimental site is described in Sect. 2. The detailed descriptions of the instruments and the measurements are given in Sect. 3. In Sect. 4, the seasonal and diurnal variations of aerosol properties are interpreted in light of local anthropogenic activities and meteorological conditions. The summary of results is given in Sect. 5 .

\section{Experimental site}

The measurements presented in this study were registered at an urban site, the city of Granada $\left(37.16^{\circ} \mathrm{N}\right.$, $3.58^{\circ} \mathrm{W}, 680 \mathrm{~m}$ a.s.1.), from 1 December 2005 to 30 November 2007. Granada, located in south-eastern Spain, is a non-industrialized medium-sized city with a population of 300000 , that increases up to 600000 if the whole metropoli$\tan$ area is considered. The city is situated in a natural basin surrounded by mountains with elevations between 1000 and $3500 \mathrm{~m}$ a.s.l. Near continental conditions prevailing at this site are responsible for large seasonal temperature differences, providing cool winters and hot summers. Most rainfall occurs during spring and winter.

The measuring station is located in the southern part of the city and is about $500 \mathrm{~m}$ away from the highway that surrounds the city and about a similar distance from one of the principal traffic roads of the city. The local aerosol sources are mainly the heavy traffic (particularly diesel vehicles) together with the re-suspension of material available on the ground, especially during the warm season when the reduced rainfall and the dryness of the terrain can increase the contribution of local mineral dust. The old part of the city has rather narrow streets responsible of heavy traffic in some areas, especially during rush hours. In winter, domestic heating 
(based on fuel oil combustion) represents an additional, important source of anthropogenic aerosols.

The bowl-like topography of Granada basin and Mediterranean climate favor winter-time inversions and the dominance of very weak wind speeds. This, in combination with pollutant emissions, can lead to a large accumulation of particles and thus high particle loads which can cause environmental and human health problems.

\section{Instruments and measurements}

Air sampling for all the instruments was obtained from the top of a stainless steel tube, 20-cm diameter and 5-m length (Lyamani et al., 2008). The inlet is fitted with a funnel and covered by an insect screen to prevent rain drops and insects from getting into the sample line. The inlet was located about $15 \mathrm{~m}$ above the ground. Measurements were performed with no aerosol size cut-off and no heating was applied to the sampled air. There is no bend in the tube that passes trough the rooftop. Several stainless steel pipes located inside the stainless steel tube provided sample air to the different instruments. Each of the stainless pipes extracts the appropriate flow for each instrument. The diameters of stainless pipes were adjusted to maintain the laminar flow in the tubes and minimize particle losses (Baron and Willeke, 2005).

Aerosol scattering $\left(\sigma_{\mathrm{sp}}\right)$ and backscattering coefficients $\left(\sigma_{\mathrm{bsp}}\right)$ were measured with an integrating nephelometer (TSI, model 3563) at three wavelengths 450,550 and $700 \mathrm{~nm}$. This instrument draws the ambient air through a temperaturemonitored inlet at a flow rate of $301 \mathrm{~min}^{-1}$, illuminates the sample with a halogen lamp and measures scattered light at 450,550 and $700 \mathrm{~nm}$ using three photomultiplier tubes. The scattered light is integrated over an angular range of $7-170^{\circ}$ from the forward direction. Using the backscatter shutter, this range can be adjusted to either $7-170^{\circ}$ or 90 $170^{\circ}$ to give total scatter and backscatter signals. Pressure and temperature are measured in the scattering chamber and used to calculate scattering by air molecules, which is then subtracted from total scattering to determine scattering by aerosol particles. Calibration of the nephelometer was carried out every three months using $\mathrm{CO}_{2}$ as a high span gas and filtered air as a low span gas. The averaging time was set to $5 \mathrm{~min}$. The zero signal was measured hourly. Due to Nephelometer design limitations, measurements do not cover the full $\left(0^{\circ}-180^{\circ}\right)$ angular range, and scattering data need correction (e.g., Anderson and Ogren, 1998; Quirantes et al., 2008). In this study, non-idealities due to truncation errors were corrected using the method described by Anderson and Ogren (1998) that account for the particle-size dependence of the truncation error through the measured wavelength dependence of light scattering.

The scattering coefficient shows a minimum dependence on relative humidity $(\mathrm{RH})$ below $50 \% \mathrm{RH}$ while a sharp increase is evident with RH above $80 \%$ (Anderson and Ogren,
1998; Xu et al., 2002). Therefore, even if the particles are not chemically dry at $\mathrm{RH}<50 \%$ they can be considered dry from a scattering point of view (Targino et al., 2005). During the study period the RH measured within the nephelometer chamber was below $50 \%$. As a result, the light scattering measurements presented in this study can be considered as dry.

The aerosol light absorption coefficient, $\sigma_{\mathrm{ap}}$, was recorded with a Multi-Angle Absorption Photometer (MAAP) (Thermo ESM Andersen Instruments, Erlangen, Germany). In this instrument, particles are deposited on a quartz fibre filter. A continuous $670 \mathrm{~nm}$ laser illuminates the filter matrix perpendicularly and simultaneous measurements are made of radiation penetrating through the filter and the radiation scattered back at two detection angles. In the MAAP, the determination of the aerosol absorption coefficient of the deposited aerosol uses radiative transfer calculations and explicitly includes a treatment of scattering effects from the filter matrix and the light scattering aerosol component. The particle-loaded filter is treated as a two-layer system: the aerosol-loaded layer of the filter and the particle-free filter matrix. Radiative processes inside the layer of deposited aerosol and between this layer and the particle-free filter matrix are taken into account separately. The two reflectivity measurements allow correction for multiple scattering processes involving the deposited particles and the filter matrix. A detailed description of the method is given by Petzold and Schönlinner (2004). The MAAP draws the ambient air at constant flow rate of $1000 \mathrm{~h} \mathrm{~h}^{-1}$ and provides $1 \mathrm{~min}$ values that are averaged to $5 \mathrm{~min}$.

At present, the MAAP is the most reliable filter-based instrument for aerosol absorption coefficient measurements (Petzold and Schönlinner, 2004; Petzold et al., 2005; Sheridan et al., 2005; Hitzenberger et al., 2006). The study of Petzold et al. (2005) and Sheridan et al. (2005) showed that the absorption coefficients measured by the MAAP are in good agreement with those measured by photoacoustic spectrometry and simultaneous measurement of aerosol extinction and aerosol scattering. Furthermore, the MAAP filter-based method does not require calibration for the measurement of the aerosol absorption coefficient and does not need post-measurement data corrections or parallel measurements of the aerosol light scattering coefficient (Petzold and Schönlinner 2004; Petzold et al., 2005).

Filters based measurements of aerosol light absorption can experience problems with particulate emissions from biomass burning or other sources of liquid organic aerosol (Subramanian et al., 2007). Recent laboratory and field measurements indicate a strong systematic positive bias of the particle soot absorption photometer in the presence of high organic aerosol concentration (Lack et al., 2008; Cappa et al., 2008). Nevertheless, only a $10 \%$ systematic bias was detected for filter based measurements of aerosol absorption by the Aethalometer in the presence of high concentration of aerosol organic carbon in Mexico City (Paredes-Miranda et 
Table 1. Summary of daily aerosol properties -Mean, Standard Deviation (SD), Maximum value and Minimum value- measured in Granada, Spain, during the period from 1 December 2005 to 30 November 2007.

\begin{tabular}{lll}
\hline Parameter & Mean \pm SD & Range \\
\hline$\sigma_{\mathrm{sp}}(450 \mathrm{~nm})\left(\mathrm{Mm}^{-1}\right)$ & $80 \pm 50$ & $15-325$ \\
$\sigma_{\mathrm{sp}}(550 \mathrm{~nm})\left(\mathrm{Mm}^{-1}\right)$ & $60 \pm 30$ & $12-234$ \\
$\sigma_{\mathrm{sp}}(700 \mathrm{~nm})\left(\mathrm{Mm}^{-1}\right)$ & $40 \pm 20$ & $9-173$ \\
$\alpha$ & $1.5 \pm 0.3$ & $0.3-2.3$ \\
$\sigma_{\mathrm{bsp}}(450 \mathrm{~nm})\left(\mathrm{Mm}^{-1}\right)$ & $11 \pm 5$ & $1-34$ \\
$\sigma_{\mathrm{bsp}}(550 \mathrm{~nm})\left(\mathrm{Mm}^{-1}\right)$ & $9 \pm 4$ & $1-27$ \\
$\sigma_{\mathrm{bsp}}(700 \mathrm{~nm})\left(\mathrm{Mm}^{-1}\right)$ & $7 \pm 3$ & $1-21$ \\
$\beta_{\mathrm{sp}}(450 \mathrm{~nm})$ & $0.13 \pm 0.01$ & $0.05-0.17$ \\
$\beta_{\mathrm{sp}}(550 \mathrm{~nm})$ & $0.14 \pm 0.02$ & $0.05-0.18$ \\
$\beta_{\mathrm{sp}}(700 \mathrm{~nm})$ & $0.17 \pm 0.02$ & $0.06-0.21$ \\
$\sigma_{\mathrm{ap}}(670 \mathrm{~nm})\left(\mathrm{Mm}^{-1}\right)$ & $21 \pm 10$ & $4-57$ \\
$\omega_{0 \mathrm{~A}}(670 \mathrm{~nm})$ & $0.68 \pm 0.07$ & $0.49-0.93$ \\
$N_{-0.5-20}\left(\mathrm{~cm}{ }^{-3}\right)$ & $30 \pm 30$ & $2-179$ \\
\hline
\end{tabular}

al., 2009). The total method uncertainty for the aerosol light absorption coefficient inferred from MAAP measurement is around 12\% (Petzold and Schönlinner 2004; Petzold et al., 2005).

An Aerodynamic Aerosol Sizer (APS-3321, TSI) was used to measure the particle size distributions and aerosol concentrations. This instrument is an optical particle counter that measures particle diameter and aerosol number density, in real time, in 52 nominal size bins in the aerodynamic diameter range $0.50-20 \mu \mathrm{m}$ by determining the time-of-flight of individual particles in an accelerating flow field. The APS can measure number densities up to 1000 particles $/ \mathrm{cm}^{3}$ at 0.5 and $10 \mu \mathrm{m}$ diameters with coincidence errors inferior to $5 \%$ and $10 \%$, respectively. The minimum and maximum number densities that this instrument can measure are 0.001 and 10000 particles $/ \mathrm{cm}^{3}$, respectively. For solid particles, counting efficiencies range from $85 \%$ to $99 \%$ (Volcken and Peters, 2003). The APS was operated at flow rate of $51 \mathrm{~min}^{-1}$ and an averaging time of $5 \mathrm{~min}$.

The columnar aerosol optical depth, $\delta_{\mathrm{a}}$, was retrieved using a CIMEL CE-318 sunphotometer (Holben et al., 1998). This instrument has a full view angle of $1.2^{\circ}$ and is equipped with 8 interferential filters and a temperature sensor for the temperature correction of the signal for temperature dependent channels. This instrument makes direct sun measurements at 340, 380, 440, 500, 670, 870, 940 and $1020 \mathrm{~nm}$ (nominal wavelengths). The direct sun measurements are then used to retrieve the aerosol optical depth at each wavelength except for $940 \mathrm{~nm}$, which is used to compute total precipitable water (Lyamani et al., 2006a). For removing cloud contaminated measurements we have used the cloud screening method developed by Smirnov et al. (2000). Periodi- cally Langley plots at high location in Sierra Nevada Range (2200 m a.s.1.) have been made to determinate the calibration constants for this instrument. The calibration measurements were carried out on completely cloud free days, with low and stable aerosol concentration. The total uncertainty in aerosol optical depth is $< \pm 0.02$ (Estellés et al., 2006).

Meteorological variables, including wind speed and temperature, used in this study were measured by an automatic weather station at the sampling site. The wind velocity was measured, at the same height of the sampling inlet, by a wind monitor model 05103 (R. M. Young Company) and the temperature was recorded by temperature sensor model MTHA1 (ITC). The error in temperature measurements is $0.4^{\circ} \mathrm{C}$ over the range $-40^{\circ} \mathrm{C}$ to $+110^{\circ} \mathrm{C}$ and the error in wind velocity is $0.3 \mathrm{~m} / \mathrm{s}$ over the range 1 to $60 \mathrm{~m} / \mathrm{s}$. Meteorological data were recorded as 1 min averages, and subsequently processed to hourly means.

Source regions responsible of special aerosol events can be detected by performing a backward trajectory analysis. To characterize the transport pathways of air masses arriving at our study area and to detect the aerosol source regions responsible of some aerosol episodes in the study area, 5-day backward trajectories ending at 12:00 UTC at Granada for 500, 1500 and $3000 \mathrm{~m}$ above ground level were calculated using the HYSPLIT model (Draxler and Rolph, 2003). The model version employed uses CDC1 Meteorological data and includes vertical wind.

\section{Results and discussions}

\subsection{Seasonal Aerosol properties variations}

\subsubsection{Aerosol scattering absorption coefficients and aerosol number density}

The temporal evolutions of daily average values of the aerosol scattering coefficient at 450, 550 and $700 \mathrm{~nm}$ and aerosol absorption coefficient at $670 \mathrm{~nm}$ measured during the period from December 2005 to November 2007 are shown in Fig. 1a and b, respectively. Table 1 presents a statistical summary of daily average aerosol optical properties measured during the entire study period. There is significant day-today variability in aerosol scattering and absorption coefficients. The daily average values of $\sigma_{\mathrm{sp}}(550 \mathrm{~nm})$ range between 12 and $234 \mathrm{Mm}^{-1}$ with a mean and standard deviation for the entire period of $60 \pm 30 \mathrm{Mm}^{-1}$ while the daily average values of the absorption coefficient at $670 \mathrm{~nm}$ vary from 4 to $57 \mathrm{Mm}^{-1}$, averaging $21 \pm 10 \mathrm{Mm}^{-1}$. Like $\sigma_{\mathrm{sp}}$ and $\sigma_{\text {ap }}$, the backscattering coefficient at $550 \mathrm{~nm}, \sigma_{\text {bsp }}(550 \mathrm{~nm})$, presents high variability ranging from 1 to $27 \mathrm{Mm}^{-1}$ with a mean value of $9 \pm 4 \mathrm{Mm}^{-1}$ for the entire period.

The lowest $\sigma_{\mathrm{sp}}\left(12 \mathrm{Mm}^{-1}\right.$ at $\left.550 \mathrm{~nm}\right)$ and $\sigma_{\text {ap }}\left(4 \mathrm{Mm}^{-1}\right.$ at $670 \mathrm{~nm}$ ) values are recorded on the same day on 19 February 2006 and are associated with a rain event. This is not 

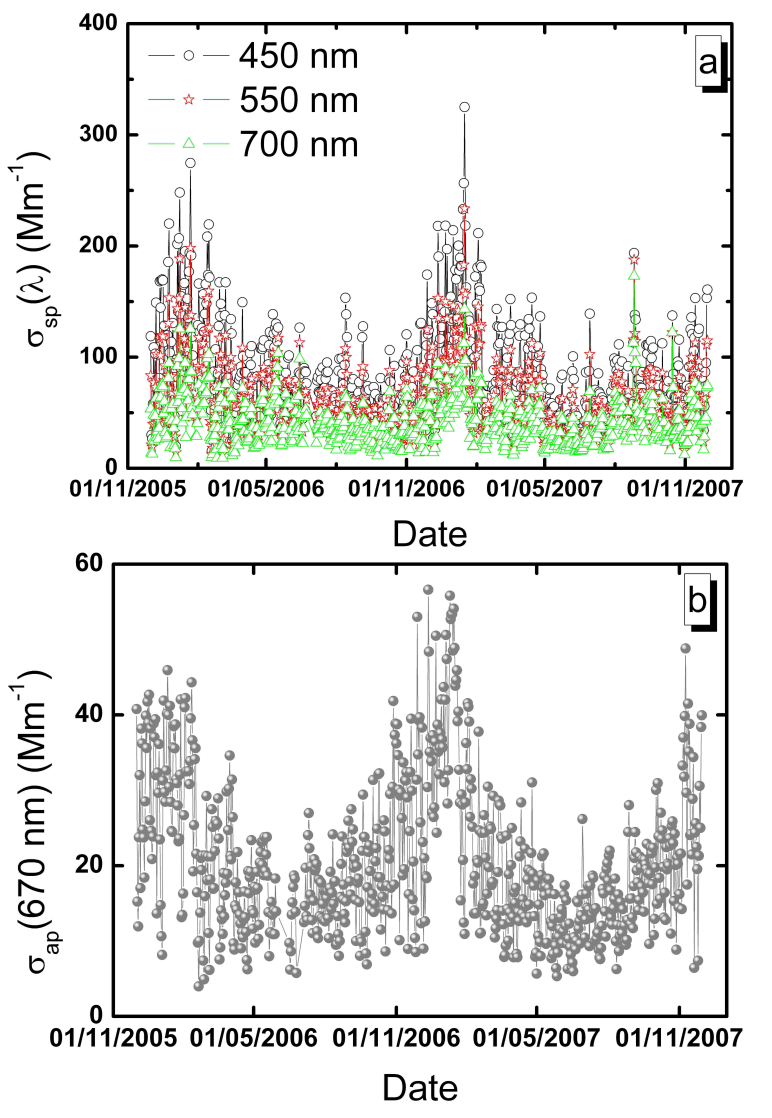

Fig. 1. Evolution of daily mean values of (a) aerosol scattering coefficient at 450, 550 and $700 \mathrm{~nm}$ and (b) aerosol absorption coefficient at $670 \mathrm{~nm}$, obtained at Granada during the period from December 2005 to November 2007.

surprising since precipitation scavenging is one of the most important atmospheric removal mechanisms of aerosol particles. In addition, air backward trajectory analysis shows that air masses reaching our study area on 19 February 2006 had originated in the Atlantic Ocean (Fig. 2a). In general, Atlantic advection with associated rain cleans the urban atmosphere and as consequence causes a large decrease in $\sigma_{\mathrm{sp}}$ and $\sigma_{\text {ap }}$ values. Pereira et al. (2008) also reported the lowest $\sigma_{\text {sp }}$ values (below $20 \mathrm{Mm}^{-1}$ ) at Evora, Portugal, under these conditions. The largest $\sigma_{\mathrm{sp}}\left(234 \mathrm{Mm}^{-1}\right.$ at $\left.550 \mathrm{~nm}\right)$ and $\sigma_{\mathrm{ap}}$ $\left(57 \mathrm{Mm}^{-1}\right.$ at $\left.670 \mathrm{~nm}\right)$ are observed on 16 January 2007 and 12 December 2006, respectively, and are linked to long range transport from North Africa (Fig. 2b and c). These results show the strong influence of mineral dust transported from North Africa on aerosol properties measured at Granada.

To analyze the seasonal variations of aerosol optical properties and the influencing factors at the study area, all data have been grouped in four seasons: winter (from December to February), spring (March to May), summer (June to August) and autumn (September to November). In Fig. 3a and b we show the seasonal variations of $\sigma_{\mathrm{sp}}$ and $\sigma_{\mathrm{ap}}$ averaged over all data available from December 2005 to November 2007.
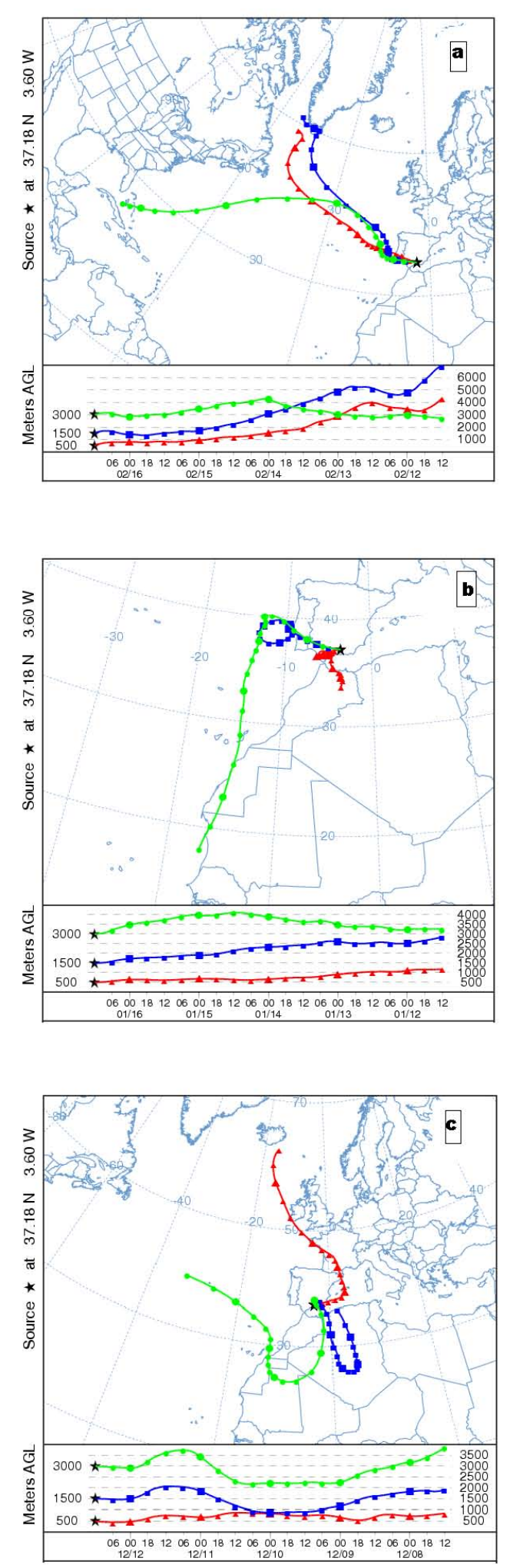

Fig. 2. 5-day backward trajectories ending at 12:00 UTC at Granada at 500, 1500 and $3000 \mathrm{~m}$ above ground level for (a) 19 February 2006, (b) 16 January 2007 and (c) 12 December 2006. 

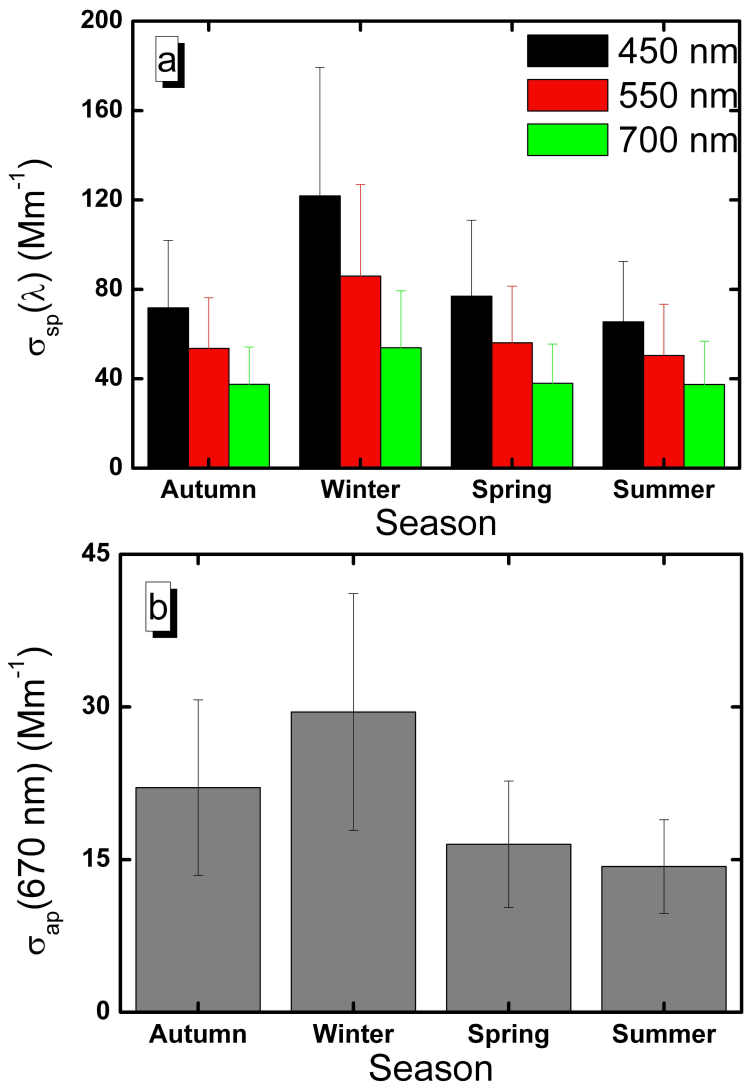

Fig. 3. Seasonal variations of (a) aerosol scattering coefficient at 450,550 and $700 \mathrm{~nm}$ and (b) aerosol absorption coefficient at $670 \mathrm{~nm}$, averaged over all data available from December 2005 to November 2007. The error bars are standard deviations.

The error bars are standard deviations. The seasonal average data are calculated from daily average data.

The largest values of scattering coefficients are obtained in winter $\left(\sigma_{\mathrm{sp}}(550 \mathrm{~nm})=90 \pm 40 \mathrm{Mm}^{-1}\right)$ while the lowest values are measured in summer $\left(\sigma_{\mathrm{sp}}(550 \mathrm{~nm})=50 \pm 23 \mathrm{Mm}^{-1}\right)$. The aerosol absorption coefficient shows a similar seasonal variation. Thus, the largest average aerosol absorption coefficient corresponds to winter $\left(30 \pm 12 \mathrm{Mm}^{-1}\right)$ while the lowest value has been obtained in summer $\left(14 \pm 5 \mathrm{Mm}^{-1}\right)$, thereby indicating larger near-surface aerosol loading during winter than in summer. As can be seen in Fig. 4a and b, the two annual cycles analyzed present similar seasonal variation of $\sigma_{\mathrm{sp}}$ and $\sigma_{\text {ap. }}$.

The standard deviations of $\sigma_{\mathrm{sp}}$ and $\sigma_{\mathrm{ap}}$ are largest during winter and lowest during summer, thus indicating a strong day to day variability in aerosol scattering and absorption coefficients during winter. This effect can be related to the variable meteorological conditions that alternate between stable anticyclonic situations, that favor trapping of particles near the surface, and the influence of frontal system, that coming from the Atlantic clean the air trough advection and/or wet deposition processes. The lowest daily variations of aerosol scattering and absorption coefficients in summer are likely
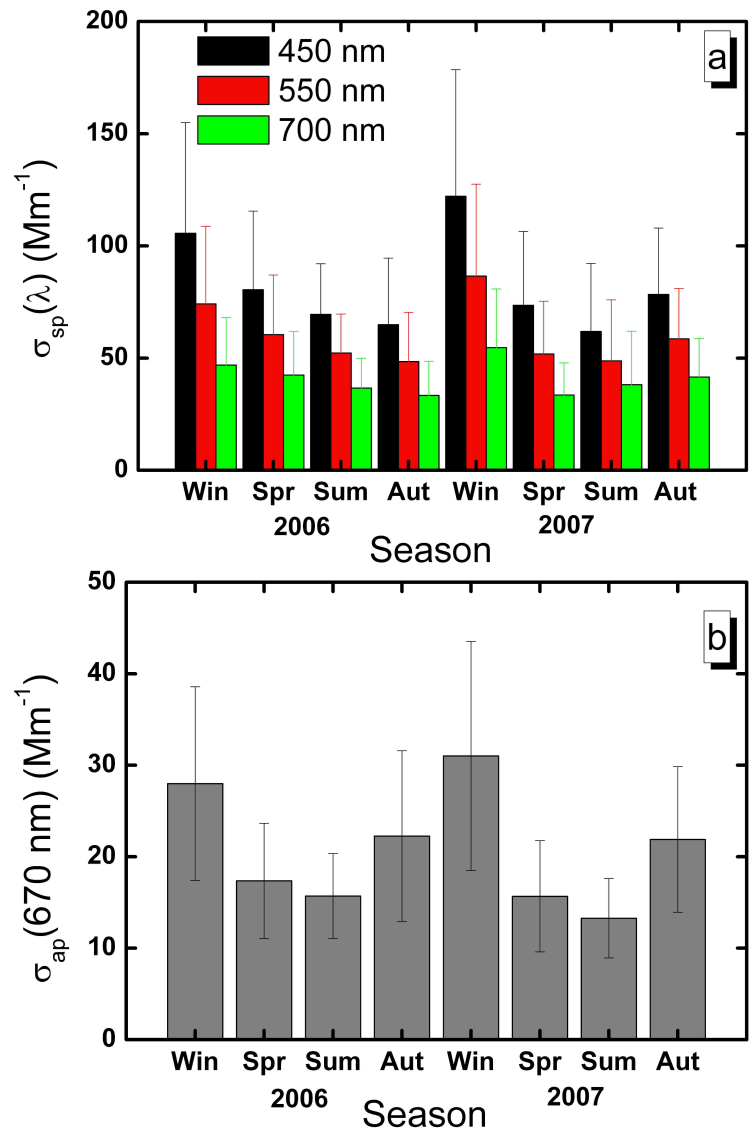

Fig. 4. Seasonal variations of (a) aerosol scattering coefficient at 450, 550 and $700 \mathrm{~nm}$ and (b) aerosol absorption coefficient at $670 \mathrm{~nm}$ obtained at Granada from December 2005 to November 2007. The error bars are standard deviations.

associated to the scarcity of rain events and the relatively less variable meteorological conditions during this season.

Winter mean aerosol scattering coefficient is larger than the summer average by a factor of 1.7 while winter mean aerosol absorption coefficient is larger than the summer counterpart by 2.1. In this way, it is evident that during winter the density of absorbing particles experiences a larger increase than that of pure scattering particles.

Figure 5a shows the seasonal variation of near surface aerosol number density $\left(N_{-0.5-20}\right)$ in the aerodynamic diameter range $0.5-20 \mu \mathrm{m}$, obtained by the APS, for both years. Measurements of aerosol number density presents a gap in autumn 2006 (between early September and the end of November) due to technical problems. For the available measurement period, daily mean values of $N_{-0.5--20}$ vary from $2 \mathrm{~cm}^{-3}$ to $179 \mathrm{~cm}^{-3}$ with an average value of $30 \mathrm{~cm}^{-3}$. The observed seasonal variation in aerosol number density is almost similar to that observed for $\sigma_{\mathrm{sp}}$ and $\sigma_{\mathrm{ap}}$ (Figs. 4 and 5a). Large values of aerosol number density are obtained during winter months $\left(4-179 \mathrm{~cm}^{-3}\right)$ while low values are measured during summer months $\left(3-69 \mathrm{~cm}^{-3}\right)$. 
Aerosol number densities measured separately in 52 different size bins in the aerodynamic diameter range 0.5$20 \mu \mathrm{m}$ by APS have been further classified into two categories, namely, "coarse" particles, $N_{-1-20}$, with aerodynamic diameters ranging between 1 and $20 \mu \mathrm{m}$ and the "fine" particles, $N_{-0.5-1}$, with aerodynamic diameters ranging between 0.5 and $1 \mu \mathrm{m}$. Coarse particles over land are mainly dust particles produced by wind blowing over land surfaces, particularly under dry conditions and in the presence of reduced vegetation cover, whereas fine particles are mainly produced by condensational growth and coagulation of nucleation mode aerosols (Seinfeld and Pandis, 1998). Figure $5 \mathrm{~b}$ and $\mathrm{c}$ show the seasonal variation of $N_{-0.5-1}$ and $N_{-1-20}$. Large values of $N_{-0.5-1}$ are observed during winter and low values during summer and autumn, with a seasonal pattern similar to those associated to aerosol scattering and absorption coefficients. In contrast, the number density of coarse particles shows the opposite pattern with values slightly larger during summer and spring.

The large values of $\sigma_{\text {sp }}, \sigma_{\text {ap }}, N_{-} 0.5-20$ and $N_{-0.5-1}$ measured during winter months can be explained by the combination of meteorological conditions and increased anthropogenic activities. Thus, in winter domestic heating (based on fuel oil combustion) contributes to increase the aerosol particles densities, especially fine particles densities, in the atmosphere, with greater impact on the absorbing particles densities. Furthermore, during winter the boundary layer is in general shallow as result of the reduced solar heating and the slightly low wind speeds. This leads to the confinement of particles near the surface and therefore to the increase in the values of $\sigma_{\text {sp }}, \sigma_{\text {ap }}, N_{-} 0.5-20$ and $N_{-} 0.5-1$. In summer, lower values of $\sigma_{\text {sp }}, \sigma_{\text {ap }}$ and $N_{-0.5-20}$ and $N_{-0.5-1}$ could be explained both by the absence of the domestic heating contribution and the enhanced thermal convection (due to the strong insolation). In this way, the vertical development of the planetary boundary layer (PBL) increases transport of air pollutants from surface aloft and thus reduces the aerosol load near surface and hence the values of $\sigma_{\mathrm{sp}}, \sigma_{\mathrm{ap}}$ and $N_{-} 0.5-20$ and $N_{-0.5-1}$. On other hand, the slightly larger wind speeds prevailing in this area in summer and spring, associated with the soil aridity during this particular period, provide a substantial dust loading from local soils to the atmosphere. On the contrary, in winter the soil is less dry than in summer and so the availability of loose soil to be lifted by wind becomes less. These factors may explain why $N_{-1-20}$ is slightly larger in summer and spring than in winter.

Saha et al. (2008) reported similar seasonal variations of aerosol scattering and absorption coefficients at an urban costal site, Toulon, France, where the largest values of $\sigma_{\mathrm{sp}}$ and $\sigma_{\mathrm{ap}}$ were observed in winter and the lowest values in summer. In addition, the mean value of $\sigma_{\mathrm{sp}}$ $\left(61 \pm 31 \mathrm{Mm}^{-1}\right.$ at $\left.550 \mathrm{~nm}\right)$ observed at Granada is similar to the $\sigma_{\mathrm{sp}}(525 \mathrm{~nm})=60 \mathrm{Mm}^{-1}$ obtained at this urban costal site during 2005-2006 (Saha et al., 2008) and is almost comparable to those obtained in northern Greece $\left(65 \pm 31 \mathrm{Mm}^{-1}\right)$
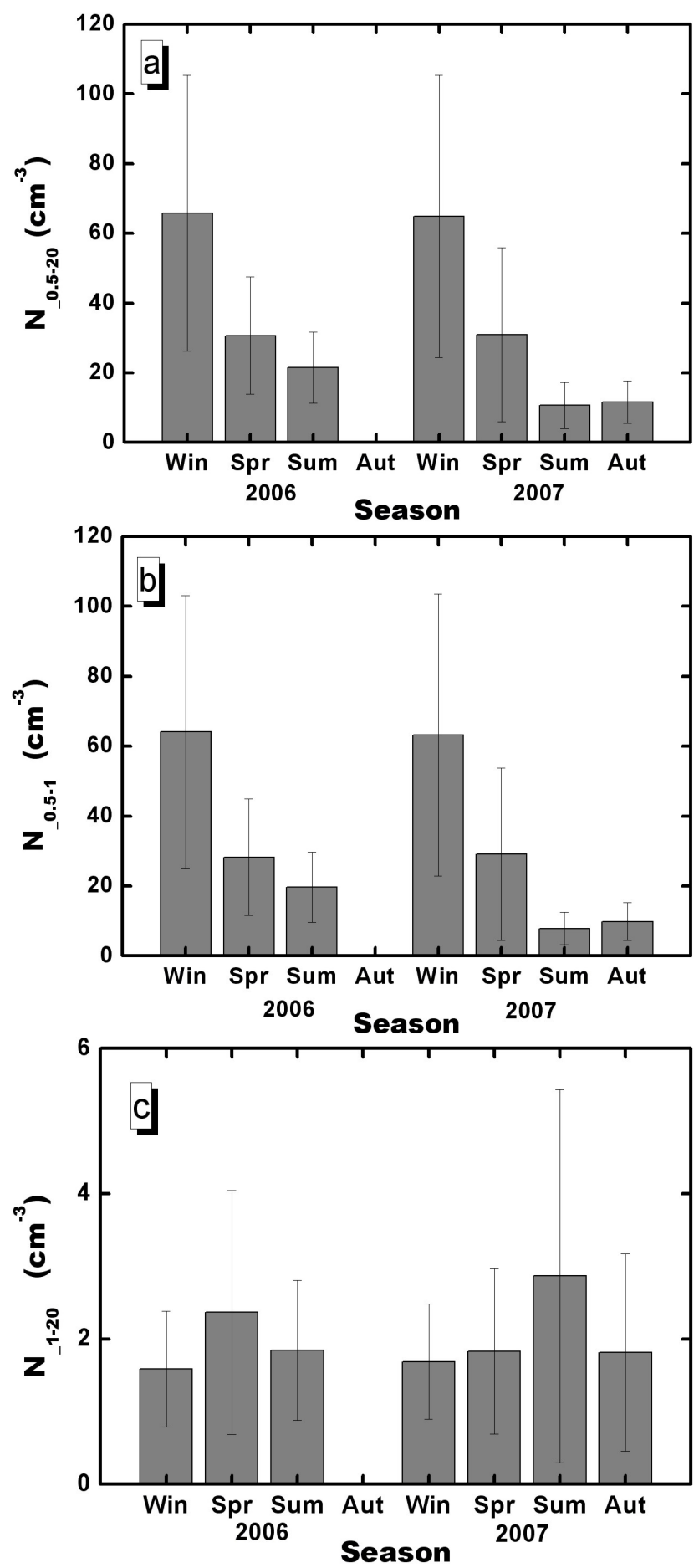

Fig. 5. Seasonal variations of number density for (a) particles in the aerodynamic diameter range $(0.5-20 \mu \mathrm{m})$, (b) "fine" particles $(0.5-$ $1 \mu \mathrm{m})$ and (c) "coarse" particles $(1-20 \mu \mathrm{m})$ measured at Granada during the period from December 2005 to November 2007. The error bars are standard deviations. 
and Sede Boker, Israel $\left(60 \pm 31 \mathrm{Mm}^{-1}\right)$ by Gerasopoulos et al. (2003) and Derimian et al. (2006), respectively. However, our $\sigma_{\mathrm{sp}}$ average value is relatively larger than the average values measured by Pereira et al. (2008), at Evora, Portugal $\left(46 \mathrm{Mm}^{-1}\right)$, and by Vrekoussis et al. (2005), in remote areas of Greece and Turkey (50 and $45 \mathrm{Mm}^{-1}$ ). Nevertheless, the measured $\sigma_{\mathrm{sp}}$ values at Granada are lower than those obtained in highly polluted areas in US (Greenwald et al., 2007; Carrico et al., 2003) and are much smaller than those observed in large urban areas in Asia (Bergin et al., 2001; Andreae et al., 2008; Garland et al., 2008; Ganguly et al., 2006). These results indicate that Granada aerosol scattering coefficient values are typical of moderately polluted urban areas.

The aerosol absorption coefficient values obtained at Granada in summer $\left(5-28 \mathrm{Mm}^{-1}\right)$ are similar to those obtained by a MAAP (the same instrument used in this study) during summer 2002 in Vienna (population 1.8 million) which ranged from $8-30 \mathrm{Mm}^{-1}$ (Hitzenberger et al., 2006). In addition, the mean value of $\sigma_{\text {ap }}\left(21 \pm 10 \mathrm{Mm}^{-1}\right)$ observed at Granada is also comparable to the values of $\sigma_{\text {ap }}$ of $22 \mathrm{Mm}^{-1}$ obtained at the urban costal Toulon, France during 2005-2006 (Saha et al., 2008). However, the summer mean aerosol absorption coefficient $\left(14 \pm 5 \mathrm{Mm}^{-1}\right)$ obtained in the present study is larger than the mean value of $8 \pm 6 \mathrm{Mm}^{-1}$ measured by Greenwald et al. (2007) in Atlanta during 2004 summer, likely as a result of the large percentage of diesel vehicles in Granada compared to Atlanta. These results indicate that Granada aerosol absorption coefficient values are typical of relatively polluted urban areas, indicating a high concentration of absorbing aerosol types.

\subsubsection{Scattering Angström exponent, aerosol single scattering albedo and backscattering ratio}

To determine the wavelength dependence of $\sigma_{\mathrm{sp}}$ we calculated the scattering Angström exponent $\alpha_{\mathrm{s}}$ associated with the scattering coefficient according to the following formula:

$\alpha_{\mathrm{s}}=-\ln \left[\sigma_{\mathrm{sp}}(700) / \sigma_{\mathrm{sp}}(450)\right] /[\ln (700 / 450)]$

The Angström exponent is an intensive parameter that depends on the aerosol size distribution - but not on the aerosol density - and that increases with decreasing particle size. For situations where scattering is dominated by particles of less than $1 \mu \mathrm{m}$ diameter (fine), the Angström exponent has values around 2; it takes on values close to 0 when scattering is dominated by (coarse) particles larger than few microns in diameter (Seinfeld and Pandis, 1998).

The seasonal averaged $\alpha_{\mathrm{s}}$ values are of $1.8 \pm 0.2,1.6 \pm 0.3$, $1.3 \pm 0.3$ and $1.4 \pm 0.3$ during winter, spring, summer and autumn, respectively. These large values of $\alpha_{\mathrm{s}}$ indicate dominance of fine particles at the site study during all seasons and that the fine particles fraction increases in winter, an observation supported by measurements of aerosol size distribution with the APS. The mean daily values of the ra- tio $N_{-} 0.5-1 / N_{-} 1-20$ - representing the relative abundance of "fine" particles over "coarse" particles - are in the range 4140 with a mean value of $40 \pm 20$ in winter months and vary between 2 and 64 with a mean of $9 \pm 8$ in summer. This large difference between summer and winter can be attributed to the increase in anthropogenic emissions (domestic heating) with greater impact on the fine particle densities. Also, during summer the contribution of large particles increases due to local dust and slightly larger wind speeds.

As scattering and absorbing particles are present together in the atmosphere, their direct effect in terms of cooling or warming of the atmosphere depends on the single scattering albedo, $\omega_{0 \mathrm{~A}}$, of the mixture of particles, which is the ratio of the scattering to the extinction coefficients of aerosol. Purely scattering particles (e.g. sulphates) exhibit values of $\omega_{0 \mathrm{~A}}=1$, while very strong absorbers (e.g. black carbon) can have values of 0.2 (Schnaiter et al., 2003). In this study, we calculated the single scattering albedo at $670 \mathrm{~nm}$ from $\sigma_{\mathrm{sp}}$ at $670 \mathrm{~nm}$, derived from nephelometer measurements using the Angström exponent, and $\sigma_{\mathrm{ap}}$ at $670 \mathrm{~nm}$ measured by the MAAP.

The seasonal averaged $\omega_{0 \mathrm{~A}}(670 \mathrm{~nm})$ values for the entire period are $0.65 \pm 0.07,0.66 \pm 0.06,0.70 \pm 0.06$ and $0.73 \pm 0.06$ during autumn, winter, spring and summer, respectively. The low values of $\omega_{0 \mathrm{~A}}(670 \mathrm{~nm})$ obtained during autumn and winter indicate an increase in the fraction of absorbing particles during these seasons, that can be related to the increase in anthropogenic activities (associated with domestic heating based on fuel oil combustion) during this period of the year, with greater impact on the absorbing particle densities. The single scattering albedo values obtained in Granada are similar to the mean value of $0.68 \pm 0.07$ obtained by Eidels-Dubovoi (2002) at Pedregal site in Mexico City. Nevertheless, the single scattering albedo measured in Granada is lower than those obtained in Marseille, France, $(0.85 \pm 0.05)$, Toulon, France, (0.73 \pm 0.07 to $0.79 \pm 0.07)$, Atlanta $(0.87 \pm 0.08)$, Beijing, China, $(0.81 \pm 0.08)$ and Guangzhou, China, $(0,82 \pm 0.05)$ by Mallet et al. (2003), Saha et al. (2008), Carrico et al. (2003), Bergin et al. (2001) and Andreae et al. (2008), respectively. The lower values of single scattering albedo in an urban area are generally related to black carbon, although dust can also contribute to aerosol light absorption (Bohren and Hoffman, 1983; Horvath, 1998). Thus, the lower scattering albedo at Granada reflects the greater relative importance of light absorbing particles and indicates that Granada's aerosols contain a large fraction of absorbing particles. As we mentioned before the extended use diesel vehicles and domestic heating based on fuel oil combustion during winter in Spain can be the cause of this increased absorption component of the atmospheric aerosols.

Aerosol scattering albedo is one of the key properties determining the effect of aerosol particles on the climate. Hansen et al. (1997) suggest that the effect of aerosol could shift from cooling to warming if the single scattering albedo goes bellow a critical value that they estimated as 0.86 . 
According to our analyses, the aerosol single scattering albedo retrieved in the surface boundary layer of Granada is below this critical value in all seasons. Thus, suggesting a possible local warming effect of the aerosol in the surface boundary layer (Ramanathan et al., 2007). In addition, heavy aerosol loading and strong aerosol absorption may result in regional and global climate changes (Xu et al., 2001; Ramanathan et al., 2001, Ramanathan and Carmichael, 2008). This put in evidence the complexity of the aerosol contribution to climate. It is obvious that efforts to reduce the emissions of sulphate and secondary organic aerosol precursors must be combined with reductions in the emission of black carbon, to avoid the accelerated warming that would result from the removal of the cooling aerosols only.

We calculated the backscatter ratio $\left(\beta_{\mathrm{sp}}\right)$ ratio as $\sigma_{\mathrm{bsp}}(550 \mathrm{~nm}) / \sigma_{\mathrm{sp}}(550 \mathrm{~nm}) . \quad$ The seasonal averaged $\beta_{\mathrm{sp}}(550 \mathrm{~nm})$ values for the entire period are $0.14 \pm 0.02$, $0.14 \pm 0.01,0.14 \pm 0.02$ and $0.14 \pm 0.01$ during autumn, winter, spring and summer, respectively. Opposite to the previously analyzed aerosol properties, $\beta_{\mathrm{sp}}$ do not show any significant seasonal pattern. This implied that $\beta_{\mathrm{sp}}$ is not sensitive to seasonal factors like meteorology and changing source emissions. This finding is similar to that of Aaltonen et al. (2006) at Pallas, a remote site in Northern Finland, where they showed that the scattering and backscattering coefficients have a clear seasonal variation while the backscattering ratio does not show a consistent seasonal pattern. Also, Bryant et al. (2006) showed that the backscattering ratio obtained at Finokalia, a remote costal site on the Greek island of Crete, exhibited little variability between July 2000 and January 2001. The mean backscatter ratio values obtained in the present study are comparable to the value of $0.13 \pm 0.02 \mathrm{Mm}^{-1}$ obtained by Andreae et al. (2002) in Sde Boker (Israel), under continental pollution conditions.

\subsubsection{Columnar aerosol optical depth and Angström exponent}

The seasonal variations of columnar aerosol optical depth, $\delta_{\mathrm{a}}(\lambda)$, for all the wavelengths measured over the entire period of our study from December 2005 to November 2007 are shown in Fig. 6. The error bars are standard deviations. The seasonal average data are calculated from daily average data. The Angström exponent, $\alpha_{\mathrm{c}}$, is calculated in the spectral interval $440-870 \mathrm{~nm}$. The columnar aerosol optical depth at all wavelengths is larger in summer $(0.23 \pm 0.10$ at $440 \mathrm{~nm})$ and lower in winter $(0.16 \pm 0.08$ at $440 \mathrm{~nm})$, thereby indicating larger columnar aerosol loading in summer than in winter. The seasonal averaged $\alpha_{\mathrm{c}}$ values for the entire period are $1.0 \pm 0.4,1.4 \pm 0.2,1.1 \pm 0.4$ and $0.8 \pm 0.4$ during autumn, winter, spring and summer, respectively, indicating dominance of fine particles during winter and an increase in the contribution of coarse particles during summer months. It is interesting to note that the seasonal variation showed

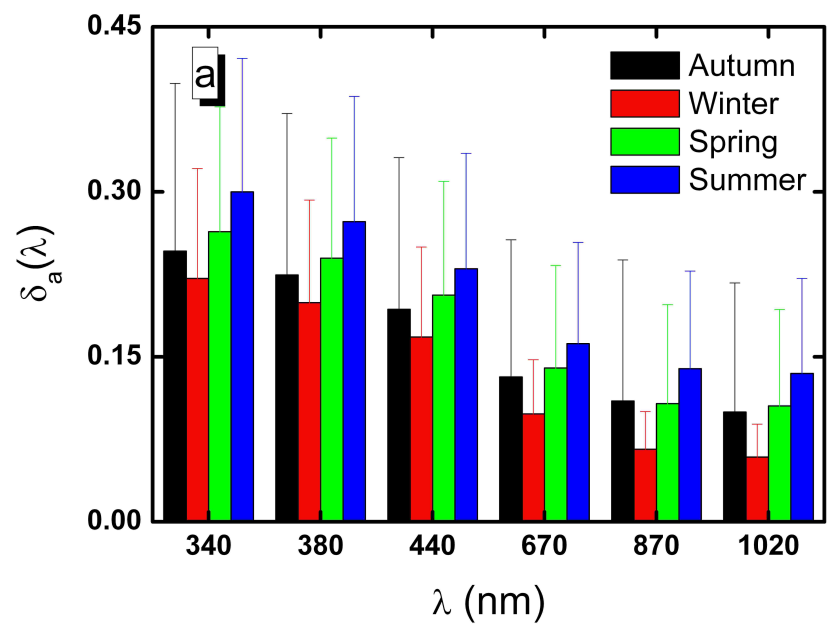

Fig. 6. Seasonal variations of columnar spectral aerosol optical depth for whole data set obtained at Granada from December 2005 to November 2007. The error bars are standard deviations.

by $\delta_{\mathrm{a}}(\lambda)$ is opposite to those shown for the case of surface aerosol properties $\left(\sigma_{\mathrm{sp}}, \sigma_{\mathrm{ap}}\right.$ and $\left.N_{T}\right)$ which presented larger values during winter and lower values during summer.

Differences in the seasonal features of surface versus columnar-integrated data can be related to seasonal variation in the aerosol vertical distribution, aerosol sources and meteorological factors. Due to its location in the Mediterranean basin, Granada is frequently affected by intrusions of Saharan dust. At Granada, most of these Saharan dust outbreaks occur in summer at high altitudes in the atmosphere (Alados-Arboledas et al., 2007a, b; Guerrero-Rascado et al., 2008) causing marked particles load in the free troposphere and therefore increasing columnar aerosol optical depth (Lyamani et al., 2005, 2006a; Alados-Arboledas et al., 2007b). At the same time, forest fires represent an additional source of aerosol particles during summer (Lyamani et al., 2006a). Recent observations at the site study have indicated that the transport of forest fire plumes occur at high altitude (Guerrero-Rascado et al., 2005; Alados-Arboledas et al., 2007b, Pérez Ramírez et al., 2008). Thus, the advection of Saharan dust and/or biomass burning aerosols to Granada may results in larger particles loading aloft in summer than in winter. Also, seasonal differences in surface and columnintegrated data may be related to the difference in the atmospheric boundary layer height. In this sense, summer convective activity increases the particles load aloft while reducing the aerosol load near the surface layer.

\subsection{Diurnal variations of aerosol properties}

\subsubsection{Aerosol scattering and absorption coefficients}

The study of diurnal variations can offer further insight into the underlying processes that control the evolution of aerosol properties in Granada, including aerosol formation 

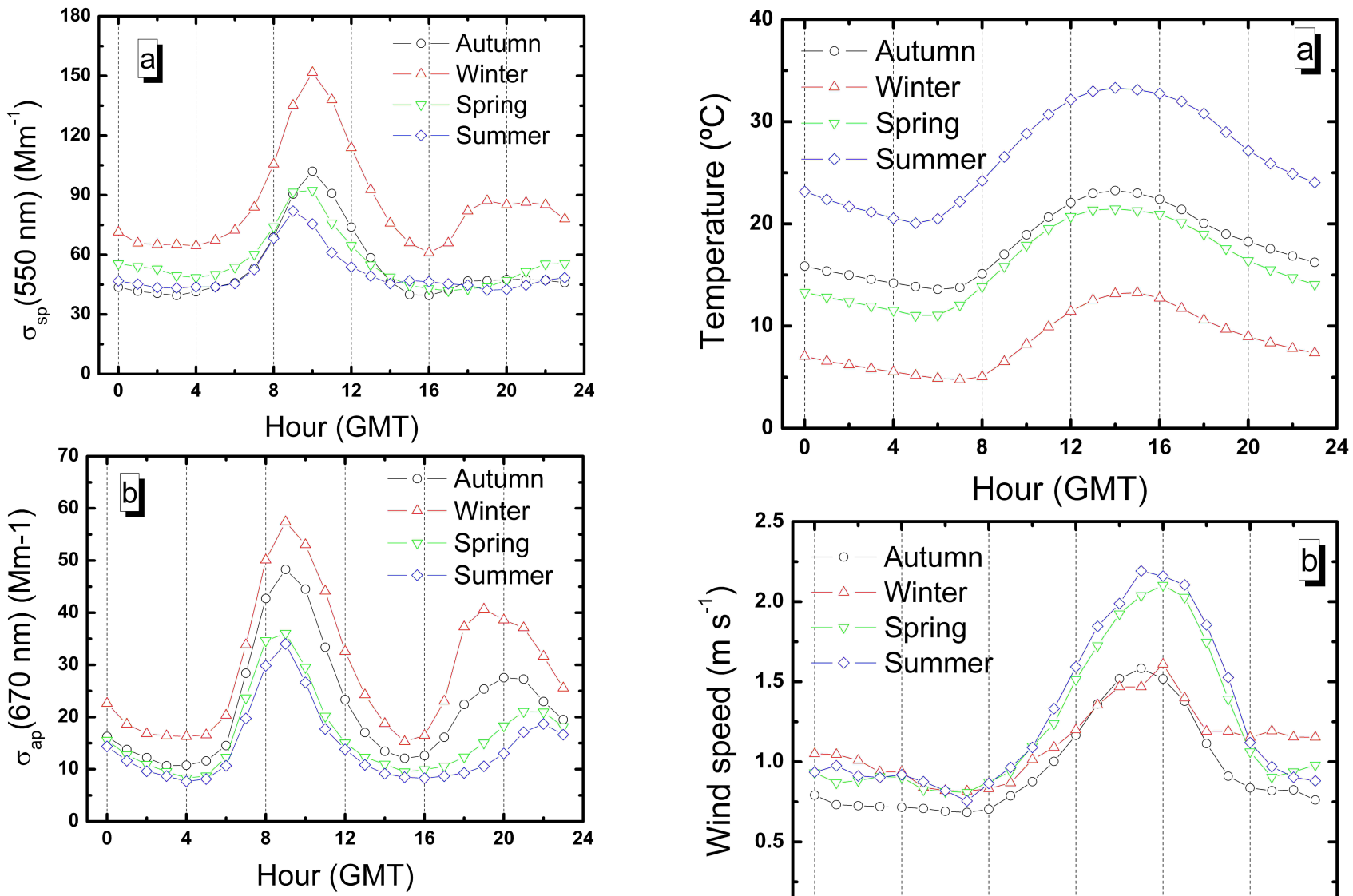

Fig. 7. Seasonal diurnal variations of (a) $\sigma_{\mathrm{sp}}(550 \mathrm{~nm})$ and (b) $\sigma_{\text {ap }}(670 \mathrm{~nm})$ averaged over all data available from December 2005 to November 2007.

mechanisms. Furthermore, a detailed examination of diurnal trends can help to identify local and regional sources. This source identification is useful to develop local and regional strategies to minimize air pollution for health and climatic reasons.

Figure 7 shows the seasonal diurnal variations of $\sigma_{\mathrm{sp}}(550 \mathrm{~nm})$ and $\sigma_{\mathrm{ap}}(670 \mathrm{~nm})$ averaged over all data available from December 2005 to November 2007. Graphical representation of the standard deviations of the mean is not shown to facilitate better visualization of the data. During all seasons, there are clear diurnal patterns in $\sigma_{\mathrm{sp}}(550 \mathrm{~nm})$ and $\sigma_{\text {ap }}(670 \mathrm{~nm})$, with two maxima and minima within a day. Both parameters reach high values in the morning between 08:00 and 11:00 GMT (local time minus one hour in winter or two hours in summer); thereafter they slowly decrease to reach minimum values in the afternoon around 15:0016:00 GMT. In the evening $\sigma_{\mathrm{sp}}$ and $\sigma_{\mathrm{ap}}$ increase and reach secondary peak values around 19:00-21:00 GMT in winter and autumn and around 21:00-24:00 GMT hours in summer and spring. Thereafter, $\sigma_{\mathrm{sp}}$ and $\sigma_{\mathrm{ap}}$ decrease slowly to attain minimum values late at night 04:00-05:00 GMT.

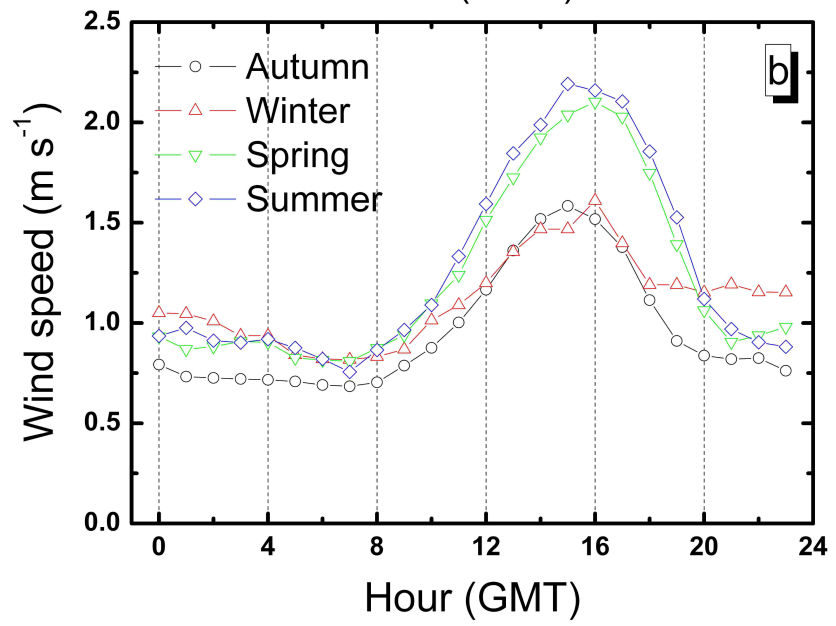

Fig. 8. Seasonal diurnal variations of (a) ambient surface temperature and (b) wind speeds averaged over all data available from December 2005 to November 2007.

These diurnal cycles are typical of urban areas (Horvath et al., 1997) and are likely due to variations in diurnal local anthropogenic activities, removal mechanisms and local meteorological conditions. The mean daily patterns of ambient surface temperature and wind speeds for different seasons of the year are shown in Fig. 8. Aerosol density is affected by the stability of the boundary layer, which is stable at night due to the surface cooling and more active during day due to increased solar heating (Navas-Guzmán et al., 2007). The boundary layer generally increases after sunrise as result of increasing solar heating, which results in mixing of clean air from above with the polluted air below. Therefore, aerosol density at surface decreases gradually due to the transport of aerosols from surface to higher levels in the atmosphere. Moreover, the increase in wind speed enhances atmospheric diffusion and consequently can reduce the aerosol density (Horvath et al., 1989). 
The large values of $\sigma_{\mathrm{sp}}$ and $\sigma_{\mathrm{ap}}$ measured early in the morning can be attributed to the intense emissions due to traffic during the morning rush hours. Furthermore, the low wind speeds (Fig. 8) and low solar heating early in the morning favor a rather low boundary layer height that cause a large particle loading near the surface and therefore high values of $\sigma_{\mathrm{sp}}$ and $\sigma_{\mathrm{ap}}$.

The subsequent slow decrease in $\sigma_{\mathrm{sp}}$ and $\sigma_{\mathrm{ap}}$ after the morning peak can be associated with the gradual increase in solar heating (Fig. 8) and convective activity which can enhance vertical particle diffusion and decrease the surface particle load. Moreover, this decrease in $\sigma_{\mathrm{sp}}$ and $\sigma_{\mathrm{ap}}$ can be related both to the gradual increase in the wind speeds (Fig. 8), which help the diffusion of particles in the atmosphere, and to the decrease in anthropogenic emissions (reduction of traffic).

The increase in $\sigma_{\mathrm{sp}}$ and $\sigma_{\mathrm{ap}}$ late in the evening can be explained by the evening traffic peak and the reduction in both boundary layer height and wind speed. Around 23:00 GMT traffic decreases drastically leading to large reductions in pollutant emissions and giving rise to minima in $\sigma_{\mathrm{sp}}$ and $\sigma_{\mathrm{ap}}$ late in the night, between 04:00-05:00 GMT.

On other hand, the scattering and absorption coefficients of the late evening peaks are lower than those of the morning peaks because the boundary layer height is typically lower in the morning than late in the evening. Furthermore, wind speeds are relatively lower in the morning than in the evening (Fig. 8). Andreae et al. (2008), in their study conducted in the area of Guangzhou, have shown that the scattering and absorption coefficients present an evident diurnal cycle, with two maxima and minima within a day. They have detected that the scattering and absorption coefficients for the late evening peaks were higher than those for the morning peaks, due to the night-time truck traffic emissions, as result of Guangzhou local traffic regulations.

Furthermore, in all seasons, the morning peak is particularly pronounced for $\sigma_{\mathrm{ap}}$. In fact, in all season, $\sigma_{\mathrm{ap}}$ show substantial increases by factor of approximately 4 from late night minima to early morning maxima, while $\sigma_{\mathrm{sp}}$ increases by factor of approximately 2 . This result indicates that local sources have a larger impact on the aerosol absorbing material than pure aerosol scattering particles. The pronounced morning peak for $\sigma_{\mathrm{ap}}$ in all seasons can be explained by the large black carbon fraction contained in fresh combustion aerosols from diesel vehicles (Ruellan and Cachier, 2001).

It is interesting to note that in winter, spring and autumn the morning and evening maximum values of $\sigma_{\text {ap }}$ occur approximately one hour earlier than those of $\sigma_{\mathrm{sp}}$. Some hypothesis could be suggested to explain these results. The delay in the scattering peak could be considered a result of the time required for secondary particle formation in the atmosphere whereas the early absorption peak could be attributed to primary particles (black carbon) from traffic emissions during rush hours. Furthermore, summer morning maxima in scattering and absorption coefficients are almost coinci-

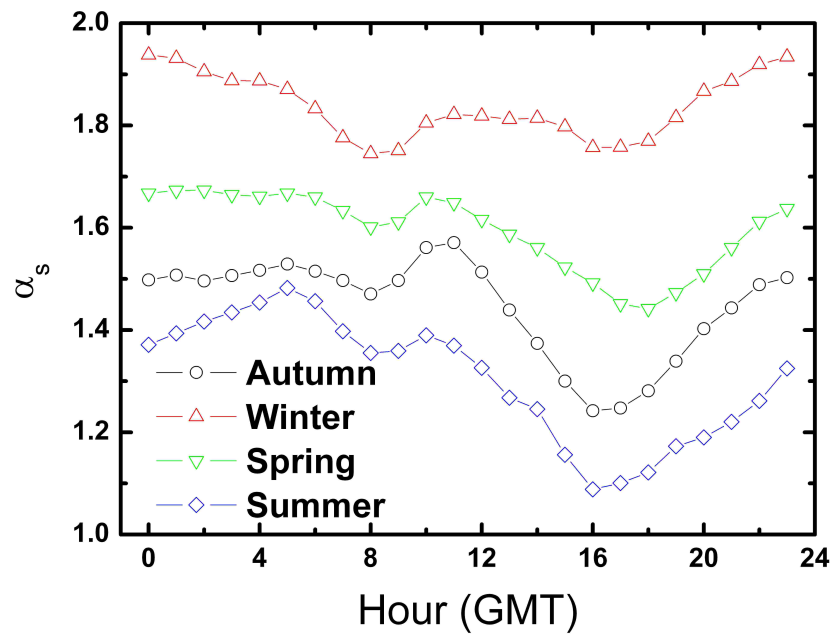

Fig. 9. Seasonal diurnal variation of scattering Angström exponent averaged over all data available from December 2005 to November 2007 .

dent. Summer dust re-suspension associated to traffic, that is an important source of scattering particles, could be suggested as a possible explanation of this result.

\subsubsection{Scattering Angstrom exponent and aerosol scattering albedo}

Figure 9 shows the seasonal diurnal cycles of hourly-average $\alpha_{\mathrm{S}}$ for the different seasons. As a common feature, all seasons present a clear diurnal pattern of the scattering Angström exponent, with large values at night and minimum values in coincidence with the morning and late afternoon traffic rush hours. During rush hours, vehicles emit fresh pollutants which are small in size, but also enhance re-suspension of road dust (large particles) into the air. Other urban studies in the Mediterranean like the one developed by Pey (2007) in the metropolitan area of Barcelona, Spain, have evidenced that during the morning and afternoon traffic rush hours there is an evident increase of the number density of both fine and coarse particles. This can explain the increased fraction of micrometric particles (minimum values of $\alpha_{\mathrm{s}}$ ) during morning and afternoon rush hours. In summer $\alpha_{\mathrm{s}}$ presents more pronounced afternoon minima in coincidence with the maxima in surface temperature and wind speed (Fig. 8). The high wind speed and the intense convective dynamics, in association with the aridity of the soils that characterizes this season, provide a high mineral dust loading to the atmosphere from local soils. This can explain the increased fraction of large particles in summer afternoons.

Figure 10 shows the average diurnal variation of single scattering albedo at $670 \mathrm{~nm}$ for the different seasons. For all seasons, the single scattering albedo shows an evident diurnal pattern with two minima, one in the morning and one in the evening, and two maxima in the afternoon and the night. 


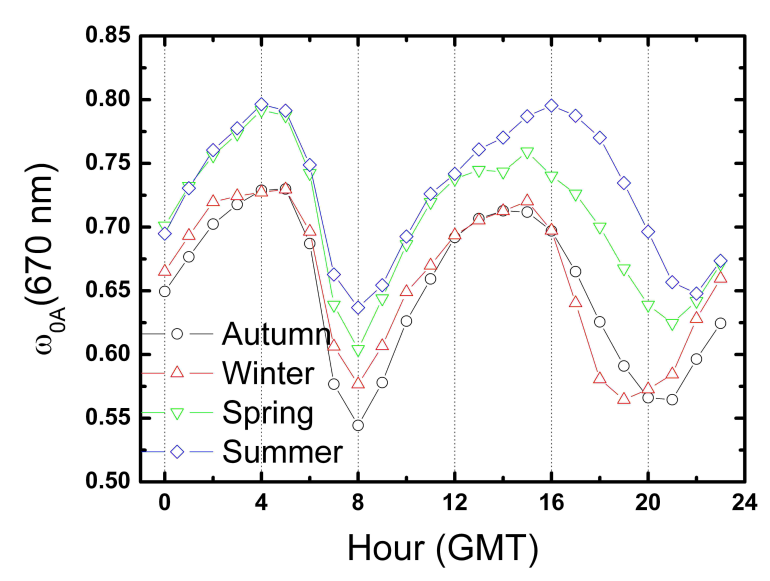

Fig. 10. Seasonal diurnal variation of single scattering albedo at $670 \mathrm{~nm}$ averaged over all data available from December 2005 to November 2007.

The daily cycle of the single scattering albedo is determined by daily variations in the aerosol scattering and absorption coefficients. Thus, the observed daily variations of the single scattering albedo, in all seasons, are due to the phase difference between daily cycles of $\sigma_{\mathrm{sp}}$ and $\sigma_{\mathrm{ap}}$. This phase difference arises from differences in the formation processes of the absorbing and scattering aerosol particles. Absorbing aerosol particles, like black carbon, are emitted directly to the atmosphere, while the majority of scattering aerosol particles, like sulphates and nitrates are secondary aerosols formed by gas-to-particle conversion processes. Thus, while absorbing aerosols (black carbon) are emitted directly by vehicles, the formation of secondary aerosols takes more time (Pey, 2007).

In all seasons, the single scattering albedo reaches minimum morning values at 08:00 GMT. These lower values of $\omega_{0 \mathrm{~A}}(670 \mathrm{~nm})$ indicate a greater relative importance of lightabsorbing particles during rush hours and the importance of traffic emissions. After 08:00 GMT, $\omega_{0 \mathrm{~A}}$ increases gradually to reach maximum values in the afternoon around 15:0016:00 GMT, depending on the season. These high afternoon values of $\omega_{0 \mathrm{~A}}(670 \mathrm{~nm})$ reveal relative increases in contribution by scattering aerosol types. Several hypotheses could be considered to explain these results. By one hand we could consider the relative continuous formation of secondary aerosols and the relative decrease in black carbon concentration, and hence in aerosol absorption, due to the decreased traffic level. The same effect could be produced if regional aerosol were advected into the urban area. After reaching a maximum, $\omega_{0 \mathrm{~A}}$ starts to decrease rather slowly to reach a second minimum around 19:00-20:00 and 21:0022:00 GMT in winter/autumn and spring/ summer, respectively. This shift in the evening minima is due to the fact that the people stay out later in summer/spring when days are longer and meteorological conditions favour outdoor activities.

\section{Conclusions}

In this study we have investigated aerosol physical and optical properties in an urban area, Granada, from December 2005 to November 2007. This has been achieved by analyzing aerosol scattering and backscattering coefficients, aerosol absorption coefficient, aerosol size distributions in the $0.5-20 \mu \mathrm{m}$ aerodynamic diameter range, wavelength dependency in aerosol scattering, aerosol scattering albedo, and backscattering ratio as well as columnar aerosol optical depth and Angström exponent.

All aerosol parameters are widely variable as a result of the variability in meteorological conditions and emissions sources. The values of aerosol properties obtained in this study are similar to those obtained in other urban areas, but with relatively large aerosol absorption coefficient values, likely due to the large contribution of diesel engines in the vehicle fleet in the study area. The aerosol scattering and absorption coefficients show a clear seasonal pattern with maxima in winter. Largest values of scattering coefficients are obtained during winter $\left(\sigma_{\mathrm{sp}}(550 \mathrm{~nm})=90 \pm 40 \mathrm{Mm}^{-1}\right)$ while lowest values are measured during summer $\left(\sigma_{\mathrm{sp}}(550 \mathrm{~nm})=50 \pm 23 \mathrm{Mm}^{-1}\right)$. Winter and autumn present larger aerosol absorption coefficient than the other season, the largest mean seasonal value correspond to winter $\left(30 \pm 12 \mathrm{Mm}^{-1}\right)$, while the lowest value is associated to summer $\left(14 \pm 5 \mathrm{Mm}^{-1}\right)$. These results indicate the presence of larger near-surface absorbing and scattering aerosols loading during winter than during summer. This seasonal cycle is opposite to the seasonal cycle shown by columnar aerosol optical depth, which exhibit larger values during summer $(0.23 \pm 0.10$ at $440 \mathrm{~nm})$ than during winter $(0.16 \pm 0.08$ at $440 \mathrm{~nm})$. This difference evidences seasonal variations in the aerosol vertical distribution associated to the atmospheric boundary layer seasonal cycle and to the seasonality of the sources of aerosol particles and of the mechanisms responsible of atmospheric transport from medium and large scales.

Large values of aerosol number density, $N_{-0.5-20}$, in the aerodynamic diameter range of $0.5-20 \mu \mathrm{m}$ are obtained during winter months (varying from 4 to $179 \mathrm{~cm}^{-3}$ ) while low values are measured during summer months (ranging between 3 and $69 \mathrm{~cm}^{-3}$ ). Large values of $\sigma_{\text {sp }}, \sigma_{\text {ap }}$ and $N_{-0.5-20}$ measured during winter can be explained by the combined effect of several factors including boundary layer dynamics and increased anthropogenic activities (domestic heating). The number density of "fine" particles, $N_{-0.5-1}$, is significantly larger in winter than in summer. In contrast, the number density of "coarse" particles, $N_{-1-20}$, is slightly larger in summer than in winter.

The scattering Angström exponent, $\alpha_{\mathrm{s}}$, presents average values of $1.8 \pm 0.2,1.6 \pm 0.3,1.3 \pm 0.3$ and $1.4 \pm 0.3$ during winter, spring, summer and autumn, respectively. This indicates dominance of fine particles at the study site during all seasons, and that the proportion of fine particles increases 
in winter while that of coarse particles increases in summer. These observations are supported by the aerosol size distribution measurements by the spectrometer APS. The mean daily values of the ratio $N_{-0.5-1} / N_{-1-20}$, which represents the relative abundance of "fine" aerosols over "coarse" particles, are in the range 4-140 with a mean value of $40 \pm 20$ in winter months, while in summer they vary between 2 and 64 with a mean of $9 \pm 8$ in summer months. This large difference between summer and winter is attributed to seasonal differences in aerosol particle sources. Thus, in winter the increases in anthropogenic emissions (domestic heating) has a larger impact on the fine particles, while the re-suspension of local mineral particles due to anthropogenic activities and the long-range transport of mineral particles from North Africa during the dry season affect mainly the coarse fraction.

The aerosols measured in our urban station, located close to main traffic arteries, and thus heavily affected by traffic, contain a large fraction of absorbing material. The average single-scattering albedo values of $0.65 \pm 0.07,0.66 \pm 0.06$, $0.70 \pm 0.06$ and $0.73 \pm 0.06$ obtained during autumn, winter, spring and summer, respectively, indicate that about $27-35 \%$ of the aerosol light extinction is accounted for by absorption. In this sense, the aerosol scattering albedo obtained in the surface boundary layer at our station is below the critical value of 0.86 that determines the shift from cooling to warming. These results put in evidence the need of efforts to reduce absorbing particles (black carbon) emissions to avoid the possible warming that would result from the reductions of the cooling aerosols only.

A clear diurnal pattern is observed in all seasons for both $\sigma_{\text {ap }}$ and $\sigma_{\text {sp }}$, with two local maxima occurring early in the morning and late in the evening. This diurnal cycle is mainly attributed to the diurnal evolution of atmospheric boundary layer and to local anthropogenic activities.

During all seasons, the scattering Angström exponent presents clear diurnal pattern with large values at night and minimum values during morning and evening traffic rush hours. However, during summer $\alpha_{\mathrm{s}}$ presents more pronounced afternoon minimum, which indicate significant contribution of large particles during this time. This pronounced minimum is coincident with maximum in surface temperature and wind speed. During all seasons, the single scattering albedo shows an evident diurnal pattern, with two minima in the morning and late evening, and two maxima in the afternoon and the night, indicating a greater relative importance of light-absorbing articles during traffic rush hours and the importance of traffic emissions.

Acknowledgements. This work was supported by the Spanish Ministry of Science and Technology through projects No: CGL2007-66477-C02-01 and CSD2007-00067 and by the Andalusian Regional Government through projects No: P06-RNM-01503 and P08-RNM-3568. The authors would like express their gratitude to the NASA/Goddard Space Flight Center, NOAA Air Resources Laboratory (ARL) for the provision of the HYSPLIT transport and dispersion model. We thank Andrew Stephen Kowalski who revised the English translation of the manuscript.

Edited by: U. Baltensperger

\section{References}

Aaltonen, V., Lihavainen, H., Kerminen, V.-M., Komppula, M., Hatakka, J., Eneroth, K., Kulmala, M., and Viisanen, Y.: Measurements of optical properties of atmospheric aerosols in Northern Finland, Atmos. Chem. Phys., 6, 1155-1164, 2006, http://www.atmos-chem-phys.net/6/1155/2006/.

Alados-Arboledas, L., Lyamani, H., and Olmo, F. J.: Aerosol size properties at Armilla, Granada (Spain), Q. J. Roy. Meteor. Soc., 129, 1395-1413, 2003.

Alados-Arboledas, A., Guerrero-Rascado, J. L., Lyamani, H., Gil, J. E., Cazorla, A., and Olmo, F. J.: Detection of May 2006 Saharan dust outbreak over Granada, Spain, by combination of active and passive remote sensing, IEEE/IGAARS 2007, Sensing and Understanding Our Planet, Barcelona, Spain, 23-27 July 2007, Cd1, 4 pp., 2007a.

Alados-Arboledas, A., Guerrero-Rascado, J. L., Lyamani, H., Navas-Guzman, F., and Olmo., F. J.: Characterization of the atmospheric aerosol by combination of LIDAR and sunphotometry, Proceedings of SPIE, Lidar Technologies, Techniques, and Measurements for Atmospheric Remote Sensing III, Florence, Italy, 17-20 September 2007, 6750, 67500J-1-67500J$8,2007 \mathrm{~b}$.

Alados-Arboledas, A., Alcántara, A., Olmo, F. J., Martínez-Lozano, J. A., Estellés, V., Cachorro, V., Silva, A. M., Horvath, H., Gangl, A., Díaz, A., Pujadas, M., Lorente, J., Labajo, A., Sorribas, M., and Pavese, G.: Aerosol columnar properties retrieved from Cimel radiometers during VELETA 2002, Atmos. Environ., 42, 2630-2642, 2008.

Anderson, T. L. and Ogren, J. A.: Determining aerosol radiative properties using the TSI 3563 integrating nephelometer, Aerosol. Sci. Tech., 29, 57-69, 1998.

Andreae, M. O., Schmid, O., Yang, H., Chand, D., Yu, J. Z., Zeng, L. M., and Zhang, Y. H.: Optical properties and chemical composition of the atmospheric aerosol in urban Guangzhou, China, Atmos. Environ., 42, 6335-6350, 2008.

Andreae, T. W., Andreae, M. O., and Ichoku, C.: Light scattering by dust and anthropogenic aerosol at a remote site in the Negev desert, Israel, J. Geophys. Res., 107(D2), 4008, doi:10.1029/2001JD900252, 2002.

Baron, P. A. and Willeke, K.: Aerosol measurement. Principles, Techniques, and applications, John Wiley and Sons, Inc. 2nd Edition, ISBN:978-0-471-78492-0, 2005.

Bergin, M. H., Gass, G., Xu, J., Zeng, L. M., Yu, T., Salmon, L. G., Kiang, C. S., Tang, X. Y., Zhang, Y. H., and Chameides, W. L.: Aerosol radiative, physical and chemical properties in Beijing during June 1999, J. Geophys. Res., 106(D16), 17969-17980, 2001.

Bohren, C. F. and Hoffman, D. R.: Absorption and scattering by small particles, John Wiley, New York, 530 pp., 1983.

Bond, T. C. and Bergstrom, R. W.: Light absorption by carbonaceous particles: An investigative review, Aerosol Sci. Technol., 40, 27-67, 2006. 
Bryant, C., Eleftheriadis, K., Smolik, J., Zdimal, N., Mihalopoulos, N., and Colbeck, I.: Optical properties of aerosols over the eastern Mediterranean, Atmos. Environ., 40(32), 6229-6244, 2006.

Cappa, C. D., Lack, D. A., Burkholder, J. B., and Ravishankara, A. R.: Bias in filter based aerosol light absorption measurements due to organic aerosol loading: Evidence from laboratory measurements, Aerosol Sci. Technol., 42(12), 1022-1032, 2008.

Carrico, C. M., Bergin, M. H., and Xu, J.: Urban aerosol radiative properties: Measurements during the 1999 Atlanta Supersite Experiment, J. Geophys. Res., 108(D7), 8422, doi:10.1029/2001JD001222, 2003.

Derimian, Y., Karnieli, A., Kaufmann, Y. J., Andreae, M. O., Andreae, T. W., Dubovik, O., Maenhaut, W., Koren, I., Holben, B. N.: Dust and pollution aerosols over the Negev desert, Israel: Properties, transport and radiative effect, J. Geophys. Res., 111, D05205, doi:10.1029/2005JD006549, 2006.

Dockery, D. W. and Pope, C. A.: Epidemiology of acute health effects: summary of time-series, in: Particles in our air: concentration and health effects, edited by: Wilson, R. and Spengler, J. D., Harvard University Press, Cambridge, MA, USA, 123-147, 1996.

Draxler, R. R., Rolph, G. D.: HYSPLIT (HYbrid Single- Particle Lagrangian Integrated Trajectory) Model access via NOAA ARL READY Website (http://www.arl.noaa.gov/ready/hysplit4.html), NOAA Air Resources Lab., Silver Spring, MD, 2003.

Dubovik, O., Holben, B., Eck, T. F., Smirnov, A., Kaufman, Y. J., King, M. D., Tanré, D., and Slutsker, I.: Variability of absorption and optical properties of key aerosol types observed in worldwide locations, J. Atmos. Sci., 59(3), 590-608, 2002.

Eidels-Dubovoi, S.: Aerosol impacts on visible light extinction in the atmosphere of Mexico City, Sci. Total Environ., 287(3), 213220, 2002.

Estellés, V., Utrillas, M. P, Martínez-Lozano, J. A., Alcántara, A., Alados-Arboledas, Olmo, F. J. L., Lorente, J., de Cabo, X., Cachorro, V., Horvath, H., Labajo, A., Vilaplana, J. M., Díaz, A. M., Díaz, J. P., Silva, A. M., Elias, T., Pujadas, M., Rodríguez, J. A., Cañada, J., and García, Y.: Intercomparison of spectroradiometers for the determination of the aerosol optical depth during the VELETA-2002 field campaign, J. Geophys. Res., 111, D17207, doi:10.1029/2005JD006047, 2006.

Foster, P., Ramaswamy, V., Artaxo, P., Berntsen, T., Betts, R., Fahey, D. W., Haywood, J., Lean, J., Lowe, D. C., Myhre, G., Nganga, J., Prinn, R., Raga, G., Schulz, M., and Van Dorland, R.: Changes in Atmospheric Constituents and in Radiative Forcing, in: Climate Change 2007: The Physical Science Basis, Contribution of Working Group I to the Fourth Assessment Report of the Intergovernmental Panel on Climate Change, edited by: Solomon, S., Qin, D., Manning, M., Chen, Z., Marquis, M. , Averyt, K. B., Tignor, M., and Miller, H. L., Cambridge University Press, Cambridge, United Kingdom and New York, NY, USA, 2007.

Ganguly, D., Jayaraman, A., and Gadhavi, H.: Physical and optical properties of aerosols over an urban area location in western India: Seasonal variabilities, J. Geophys. Res., 111, D24206, doi:10.1029/2006JD007392, 2006.

Garland, R. M., Yang, H., Schmid, O., Rose, D., Nowak, A., Achtert, P., Wiedensohler, A., Takegawa, N., Kita, K., Miyazaki, Y., Kondo, Y., Hu, M., Shao, M., Zeng, L. M., Zhang, Y. H., Andreae, M. O., and Pöschl, U.: Aerosol optical properties in a rural environment near the mega-city Guangzhou, China: implications for regional air pollution, radiative forcing and remote sensing, Atmos. Chem. Phys., 8, 5161-5186, 2008, http://www.atmos-chem-phys.net/8/5161/2008/.

Gerasopoulos, E., Andreae, M. O., Zerefos, C. S., Andreae, T. W., Balis, D., Formenti, P., Merlet, P., Amiridis, V., and Papastefanou, C.: Climatological aspects of aerosol optical properties in Northern Greece, Atmos. Chem. Phys., 3, 2025-2041, 2003, http://www.atmos-chem-phys.net/3/2025/2003/.

Greenwald, R., Bergin, M. H., Sullivan, A., and Weber, R.: Sizeresolved, real-time measurement of water-insoluble aerosols metropolitan Atlanta during the summer of 2004, Atmos. Environ., 41, 519-531, 2007.

Guerrero-Rascado, J. L., Gil, J. E., Morales, N., and AladosArboledas, L.: Lidar measurement in South Eastern Spain, Abstract of the European Aerosol Conference, Ghent, Belgium, 28 August-2 September 2005, 1, 396, 2005.

Guerrero-Rascado, J. L., Ruiz, B., and Alados-Arboledas, L.: Multi-spectral Lidar characterization of the vertical structure of Saharan dust aerosol over southern Spain, Atmos. Environ., 42, 2668-2681, 2008.

Guerrero-Rascado, J. L., Olmo, F. J., Avilés-Rodríguez, I., NavasGuzmán, F., Përez-Ramrez, D., Lyamani, H., and Alados Arboledas, L.: Extreme Saharan dust event over the southern Iberian Peninsula in september 2007: active and passive remote sensing from surface and satellite, Atmos. Chem. Phys., 9, 84538469, 2009, http://www.atmos-chem-phys.net/9/8453/2009/.

Hansen, J., Sato, M., and Ruedy, R.: Radiative forcing and climate response, J. Geophys. Res., 102(D6), 6831-6864, 1997.

Haywood, J. M. and Shine, K. P.: Multi-spectral calculations of the direct radiative forcing of tropospheric sulphate and soot aerosols using a column model, Q. J. Roy. Meteor. Soc., 123, 1907-1930, 1997.

Haywood, J. and Boucher, O.: Estimates of the direct and indirect radiative forcing due to tropospheric aerosols: a review, Rev. Geophys., 38, 513-543, 2000.

Heintzenberg, J.: Size-segregated measurements of particulate elemental carbon and aerosol light absorption at remote artic locations, Atmos. Environ., 16, 2461-2469, 1982.

Hitzenberger, R., Petzold, A., Bauer, H., Ctyroky, P., Pouresmaeil, P., Laskus, L., and Puxbaum, H.: Intercomparison of thermal and optical measurement methods for elemental carbon and black carbon at an urban location, Environ. Sci. Technol., 40, 63776383, 2006.

Holben, B. N., Eck, T. F., Slutsker, I., Tanré, D., Buis, J.P., Setzer, A., Vermote, E., Reagan, J. A., Kaufman, Y. J., Nakajima, T., Lavenu, F., Jankowiak, I., and Smirnov, A.: AERONET -A federated instrument network and data archive for aerosol characterization, Remote Sens. Environ., 66(1), 1-16, 1998.

Horvath, H., Habenriech, T.A., Kreiner, I., Norek, C.: Temporal and spatial variations of the Vienna aerosol, Sci. Total Environ., 83, 127-159, 1989.

Horvath, H.: Estimation of the average visibility in central Europe, Atmos. Environ., 29, 241-246, 1995.

Horvath, H., Catalan, L., and Trier, A.: A study of aerosol of Santiago de Chile III: Light absorption measurements, Atmos. Environ., 31, 3737-3744, 1997.

Horvath, H.: Influence of atmospheric aerosols upon the global ra- 
diation balance, in atmospheric particles, edited by: Harrison, R. M. and van Grieken, R., 543-596, John Wiley, Hoboken, N. J, 1998.

Jacobson, M. Z.: Strong radiative heating due to the mixing state of black carbon in atmospheric aerosols, Nature, 409, 695-697, 2001.

Kaufman, Y. J., Koren, I., Remer, L. A., Rosenfeld, D., and Rudich, Y.: The effect of smoke, dust, and pollution aerosol on shallow cloud development over the Atlantic Ocean, Proceedings of the National Academy of Sciences of the United States of America, 102(32), 11207-11212, 2005.

Lack, D. A., Cappa, C. D., Covert, D. S., Baynard, T., Massoli, P., Sierau, B., Bates, T. S., Quinn, P. K., Lovejoy, E. R., and Ravishankara, A. R.: Bias in filter based aerosol absorption measurements due to organic aerosol loading: Evidence from ambient measurements, Aerosol Sci. Technol., 42(12), 1033-1041, 2008.

Lyamani, H., Olmo, F. J., and Alados-Arboledas, L.: Saharan dust outbreak over south-eastern Spain as detected by sun photometer, Atmos. Environ., 39, 7276-7284, 2005.

Lyamani, H., Olmo, F. J., Alcántara, A., and Alados-Arboledas, L.: Atmospheric aerosols during the 2003 heat wave in southeastern spain I: Spectral optical depth, Atmos. Environ., 40, 6453-6464, 2006a.

Lyamani, H., Olmo, F. J., Alcántara, A., and Alados-Arboledas, L.: Atmospheric aerosols during the 2003 heat wave in southeastern spain II: Microphysical columnar properties and radiative forcing, Atmos. Environ., 40, 6465-6476, 2006b.

Lyamani, H., Olmo, F. J., and Alados-Arboledas, L.: Light scattering and absorption properties of aerosol particles in the urban environment of Granada, Spain, Atmos. Environ., 42, 2630-2642, 2008.

Mallet, M., Roger, J. C., Despiau, S., Dubovik, O., and Putaud, J. P.: Microphysical and optical properties of aerosol particles in urban zone during ESCOMPTE, Atmos. Res., 69, 73-97, 2003.

Navas-Guzmán, F., Guerrero-Rascado, J. L., Fernández-Medina, A. B., Adame, J. A., and Alados-Arboledas, L.: Mixing layer height determination by Lidar and radiosounding data, European Aerosol Conference 2007, Salzburg, Austria, 9-14 September 2007, Cd1, T20A014, 2007.

Olmo, F. J. and Alados-Arboledas, L.: Pinatubo eruption effects on solar radiation at Almería, Tellus, 47B, 602-606, 1995.

Paredes-Miranda, G., Arnott, W. P., Jimenez, J. L., Aiken, A. C., Gaffney, J. S., and Marley, N. A.: Primary and secondary contributions to aerosol light scattering and absorption in Mexico City during the MILAGRO 2006 campaign, Atmos. Chem. Phys., 9, 3721-3730, 2009, http://www.atmos-chem-phys.net/9/3721/2009/.

Pereira, S., Wagner, F., and Silva, A. M.: Scattering properties and mass concentration of local and long range transported aerosols over the south western Iberian Peninsula, Atmos. Environ., 42, 7623-7631, 2008.

Pérez-Ramírez, D., Aceituno, J., Ruiz, B., Olmo, F. J., and AladosArboledas, L.: Development and calibration of star photometry to measure the aerosol optical depth: Smoke observations at a high mountain site, Atmos. Environ., 42, 2733-2738, 2008.

Petzold, A. and Schönlinner, M.: Multi-angle Absorption photometry-A new method for the measurement of aerosol light absorption and atmospheric black carbon, J. Aerosol Sci., 35, 421-441, 2004.
Petzold, A., Schloesser, H., Sheridan, P. J., and Arnott, W. P.: Evaluation of multi-angle Absorption photometry for measuring aerosol light absorption, Aerosol Sci. Technol., 39(1), 40-51, 2005.

Pey, J.: Caracterización fisico-química de los aerosoles atmosféricos en el Mediterráneo occidental, Ph.D. thesis, Departament d'Enginyeria Minera i Recursos Naturals, Polytechnic University of Catalunya, Spain, 2007.

Quirantes, A., Olmo, F. J., Lyamani, H., and Alados-Arboledas, L.: Correction factors for a total scatter/backscatter nephelometer, J. Quant. Spectrosc. Ra., 109, 1496-1503, 2008.

Ramanathan, V., Crutzen, P. J., Kiehl, J. T., and Rosenfeld, D.: Aerosols, Climate, and hydrological cycle, Science, 7, 21192124, 2001.

Ramanathan, V., Raman, M. V., Roberts, G., Kim, D., Chung, C. and Winker, D.: Warming trends in Asia amplified by brown cloud solar absorption, Nature, 448, 575-578, 2007

Ramanathan, V. and Carmichael, G.: Global and regional changes due to black carbon, Nature Geoscience, 1, 221-227, 2008.

Ruellan, S. and Cachier, H.: Characterization of fresh particulate vehicular exhaust near a Paris high flow road, Atmos. Environ., 35, 435-468, 2001.

Saha, A., Mallet, M., Roger, J. C., Dubuisson, P., Piazzola, J., and Despiau, S.: One year measurements of aerosol optical properties over an urban coastal site: Effect on local direct radiative forcing, Atmos. Res., 90, 195-202, 2008.

Schnaiter, M., Horvath, H., Möhler, O., Naumann, K. H., Saathoff, H., and Schöck, O. W.: UV-VIS-NIR spectral optical properties of soot and soot-containing aerosols, J. Aerosol Sci., 34, 14211444, 2003.

Schwartz, S. E., Arnold, F., Blanchet, J. P., Durke, P. A., Hofmann, D. J., Hoppel, W. A., King, M. D., Lacis, A. A., Nakajima, T., Ogren, J. A., Toon, O. B., and Wendisch, M.: Group report: connections between aerosol properties and forcing of climate, in: Aerosol of Climate, edited by: Heintzenberg, J. and Charlson, R. J., Wiley, New York, 251-280, 1995.

Seinfeld, J. H. and Pandis, S. N.: Atmospheric chemistry and physics: From air pollution to climate change, 1326 pp., John Wiley, New York, 1998.

Sheridan, P. J., Arnott, W. P., Ogren, J. A., Anderson, B. E., Atkinson, D. B., Covert, D. S., Moosmüller, H., Petzold, A., Schmid, B., Strawa, A. W., Varma, R., and Virkkula, A.: The Reno aerosol optics study: An evaluation of aerosol absorption measurement methods, Aerosol Sci. Techol., 39, 1-16, 2005.

Smirnov, A., Holben, B. N., Eck, T. F., Dubovik, O., and Slutsker, I.: Cloud-screening and quality control algorithms for the AERONET database, Remote Sens., 73(3), 337-349, 2000.

Subramanian, R., Roden, C. A., Boparai, P., and Bond, T. C.: Yellow beads and missing particles: Trouble ahead for filter based absorption measurements, Aerosol Sci. Techol., 41, 630-637, 2007.

Targino, A. C., Noone, K. J., and Öström, E.: Airborne in situ characterization of dry aerosol optical properties in multisource influenced marine region, Tellus, 57B(3), 247-260, 2005.

Volckens, J. and Peters, T. M.: Counting and particle transmission efficiency of the aerodynamic particle sizer, J. Aerosol Sci., 36, 1400-1408, 2005. 
Vrekoussis, M., Liakakou, E., Kocak, M., Oikonomou, K., sciare, J., and Mihalopoulos, N.: Seasonal variability of optical properties of aerosols in the eastern Mediterranean, Atmos. Environ., 39, 7083-7094, 2005.

Waggoner, A. P., Weiss, R. E., Ahlquist, N. C., Covert, D. S., Will, S., and Charlson, R. J.: Optical characteristics of atmospheric aerosols, Atmos. Environ., 15, 1891-1909, 1981.
Xu, J., Bergin, M. H., Yu, X., Liu, G., Zhao, J., Carrico, C. M., and Baumann, K.: Measurement of aerosol chemical, physical and radiative properties in the Yangtze delta region of China, Atmos. Environ., 36, 161-173, 2002.

$\mathrm{Xu}, \mathrm{Q}$.: Abrupt change of the mid-summer climate in central east China by the influence of atmospheric pollution, Atmos. Environ., 35, 5029-5040, 2001. 